ISSN 0103-5150

Fisioter. Mov., Curitiba, v. 30, n. 3, p. 595-605, Jul./Sep. 2017

Licenciado sob uma Licença Creative Commons

DOI: http://dx.doi.org/10.1590/1980-5918.030.003.AR01

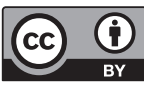

\title{
Educational approaches focusing on the quality of life of people with chronic kidney disease receiving hemodialysis: an integrative review
}

\section{Abordagens educativas focalizando a qualidade de vida da pessoa com doença renal crônica em hemodiálise: uma revisão integrativa}

\author{
Pedro Cezar Beraldo ${ }^{[a]}$, Simone Tetu Moysés ${ }^{[a]}$, Renata Iani Werneck ${ }^{[a]}$, Eduardo Santana de Araujo ${ }^{[b]}$, \\ Samuel Jorge Moysés ${ }^{[\mathrm{a}] *}$ \\ [a] Pontifícia Universidade Católica do Paraná (PUCPR), Curitiba, Paraná, Brazil \\ [b] Universidade de São Paulo (USP), São Paulo, SP, Brazil
}

\section{Abstract}

Introduction: The impact of chronic kidney disease (CKD) on the quality of life of patients receiving hemodialysis is widely studied. Despite the vast amount of literature on the topic, it is still important to investigate the educational approaches related to this population's quality of life, evolution, and treatment. Objective: To systematically review the literature on educational approaches focusing on people with CKD receiving hemodialysis. Methods: An integrative systematic review of studies published between 2010 and 2015 was conducted using the PubMed, LILACS, PROQUEST, SCIENCEDIRECT, and SciELO databases using the keywords "quality of life and hemodialysis and adults", with their translation equivalents in Portuguese and Spanish. Results: The studies included in this review investigated biological conditions, treatment adherence, psychosocial conditions, and even spiritual influence. These studies unanimously recognized the validity of educational approaches, be it for treatment adherence, actor's empowerment, or self-knowledge, as well as the importance of addressing a wider patient view and participatory therapy planning. Conclusion: The quality of life of people with CKD is a widely and differently studied topic, but the number of educational approaches focusing on this group of patients is modest and poorly represented in the existing literature. The few studies that address this topic are in complete agreement about the importance and relevance of educational approaches for people

* PCB: PhD Student, e-mail: p.beraldo@pucpr.br STM: PhD, e-mail: simone.moyses@pucpr.br RIW: PhD, e-mail: renata.iani@pucpr.br ESA: PhD, e-mail: hodu.santana@gmail.com SJM: PhD, e-mail: s.moyses@pucpr.br 
with CKD. We conclude that patient adherence, participation, and empowerment should be considered and encouraged.

Keywords: Education. Health. Quality of Life. Hemodialysis. Adults

\section{Resumo}

Introdução: Qualidade de vida é tema amplamente estudado, como forma de compreender as repercussões causadas na vida das pessoas com doença renal crônica - DRC em hemodiálise. Apesar da vasta literatura sobre o tema, ainda é útil interrogar sobre as abordagens que se ocupam de processos educativos relacionados à qualidade de vida, nessa população, sua evolução e tratamento. Objetivo: Revisar sistematicamente a literatura quanto a propostas de natureza educativa, na abordagem a pessoas com DRC em hemodiálise. Métodos: Revisão sistemática integrativa de estudos publicados entre 2010 a 2015, nas bases: PubMed, LILACS, PROQUEST, SCIENCE DIRECT e SCIELO; termos de busca "qualidade de vida e hemodiálise e adultos", com seus equivalentes em inglês e espanhol. Resultados: As publicações incluídas na revisão perpassaram abordagens de condições biológicas, adesão ao tratamento, condição psicossocial e, inclusive, a influência espiritual. Os estudos foram unânimes em reconhecer a validade dos processos educativos, quer sejam de adesão ao tratamento; de empoderamento dos atores; da importância de autoconhecimento; da necessária visão ampla sobre o paciente e da importância do planejamento participativo na abordagem terapêutica. Conclusão: a exploração do tema qualidade de vida em pessoas com DRC é ampla e diversificada, sendo sua abordagem educativa discreta e pouco representativa quanto ao número de publicações disponíveis. Os poucos estudos que tratam do tema são unânimes em reconhecer a importância e relevância das abordagens educativas para pessoas com DRC. Conclui-se que a adesão, a participação e a emancipação dos pacientes devam ser consideradas e encorajadas.

Palavras-chave: Educação. Saúde. Qualidade de Vida. Hemodiálise. Adultos.

\section{Introduction}

Chronic kidney disease (CKD) treatment has become complex and expensive $(1,2,3)$. Nevertheless, retrieval of renal function by dialysis and/or transplant do not prove sufficient. Patients need to understand and get involved in treatment, proposals, choices and decisions (4 - 6).

Hemodialysis (HD) - one of the main treatment procedures for terminal renal failure - currently involves problematic life situations. Getting up early and having to wait for public, collective transport; being weighed, having to wait for the installation of the machine, sharing the therapeutic space and the hemofiltration machine are only some of the inconveniences that people with CKD have to go through and that end up affecting their routines and life habits. Moreover, not being allowed to drink or eat whatever their eyes, nose or taste buds tell them; experiencing sleepless nights, body aches, itching, changes in appearance, hunger, thirst and cold due to metabolic changes; and having to deal with the fear of having their blood pass through a machine that is only slightly similar to their body's physiological conditions are just but a few of the factors that complicate this scenario. Added to this, there is also the difficulty of fully participating in society, the incapability of having a paid employment, be it due to the combination of symptoms they experience or due to the difficulty of the working normal working hours. Not being able to simply travel and satisfy their personal wishes when they have the means to do so, without having to search for alternative dialysis units on the way, worrying about exams and acceptance in another center, the limited time that they can stay away from home, or the risk of contamination, are conditions that contribute to the create situations of lack of information about one's own body and life (5, 7 - 9).

According to physiologists, a healthy human organism works like an "automaton", i.e., it is capable of self-regulating elementary functions for the 
maintenance of life. We eat because we feel hungry, we drink because we feel thirsty, we sleep because we feel sleepy, we go to the toilet when we feel the need, and even during the night, we keep self-regulating ourselves, breathing, filtering and excreting. People with CKD lose this automatism and the control over basic organic functions $(7,10,11)$.

Being a chronic kidney disease patient is the equivalent of losing this self-regulating autonomy and having to depend on complex therapeutic procedures that include much more than hemodialysis. As a general rule, health care models and practices are influenced by actions destined for acute diseases, even in the case of people with chronic diseases/conditions. The biomedical model of medicine included actions in which the "patient" is a passive component in the process of care. Health professionals adopt a prescriptive posture and health care actions are episodic. Intervention models for acute diseases are not effective for chronic diseases, and that for several reasons $(10$ - 12). Because of their long duration and high morbidity, chronic kidney diseases may not be resolved through episodic actions. In order to be successful, interventions should include continuous health education strategies that promote treatment adherence $(7,13,14,15)$.

Adherence is not easy to achieve and many conditions may interfere in this process, such as: support networks (family, friends and people close to the patient can positively or negatively interfere with the process), educational level (cognitive ability is associated with people's education, and the educational process depends on this condition), acceptance of the disease (characterized as the conscious manner in which people deal with their health conditions, as active and co-responsible subjects), therapy side effects (it is important that patients are aware of side effects and how to deal with them), complex treatment regimen (it is important to know each part of the therapeutic approach, its reason and importance), long-term treatment (understanding that a chronic disease has a long duration and is full of difficulties that must be encountered), absence of symptoms (when not perceived, they give a false impression of improvement or healing, and may further complicate the overall picture), among others $(8,15,16)$.

It has been stressed, especially in developed countries, that adherence to treatment should be considered as very important, if not indispensable, for achieving successful results. The Brazilian health system throughout the decades indicates the need for concrete "health education" projects (17).

Data published by the Brazilian Society of Nephrology in 2015 showed that 100,000 people in Brazil are on dialysis therapy. There are currently 750 registered dialysis treatment units in Brazil, of which 35 alone are located in the city of Sao Paulo. The figures show that $70 \%$ of the patients who are on dialysis treatment only discover the disease at a late stage. Mortality rate for people in treatment is $15 \%$ (18).

End-stage kidney disease has been linked to two conditions related to non-communicable chronic diseases (NCCDs), namely diabetes mellitus and hypertension. Hypertension is directly associated with unhealthy aging and often behaves like a silent condition, hindering diagnosis and early treatment, which could minimize its consequences. Therefore, the increase in life expectancy has contributed to the appearance of a new morbidity and mortality profile, in which chronic conditions, including kidney disease, prevail. (18).

Epidemiological transition makes CKD one of the major public health challenges of this century, because of all its implications, not only those directly associated with health care, but also economic and social causes that affect the individual, the family and the health system itself (19 - 22).

It is increasingly apparent that simply being alive is not enough. The current literature evidences experts concern about the inclusion of the quality of life (QoL) topic in approaches directed at patients with CKD receiving hemodialysis. $(18,19,21$ - 23). However, these QoL approaches are often indirect and insufficient, especially when it comes to their educational content.

Since there is no rapid improvement in CKD and it has a progressive evolution, which causes biological, social and economic problems, it is necessary to plan a medium - and long - term approach (8, $22,24)$. It is known that more than half of patients with CKD receiving hemodialysis do not adhere to at least part of their proposed treatment regimens. Results show rates of non-adherence ranging from 8.5 to $86.0 \%$. Moreover, blood filtering alone is not enough. Treatment for kidney patients should also include fluid restriction, diet, adherence to medication, body self-care and active participation in hemodialysis treatment. Therefore, it is essential that educational processes are used as part of treatment $(3,5,20,23,25)$. 
Given the above, the purpose of this paper is to review the specialized literature on educational approaches focusing on the quality of life of people with CKD receiving hemodialysis, their families and/or professionals involved in the treatment, emphasizing the importance of making investments and implementing strategies that contribute to their empowerment.

\section{Methods}

An integrative systematic review of the literature was conducted to answer the following question: what is the evidence of educational approaches emphasizing quality of life indicators and focusing on people with CKD receiving hemodialysis? We reviewed papers published between 2010 and 2015, it was conducted using the PubMed, LILACS, PROQUEST, SCIENCEDIRECT and SciELO databases using the keywords "education, and health, and quality of life, and hemodyalisis, and adults not peritoneal dialysis not transplant" with their translation equivalents in Portuguese and Spanish.
2.690 papers were retrieved using these keywords. After applying the first filter (i.e., peerreviewed texts, articles available in full text) and reading the titles of the papers to check the occurrence of the searched words, 229 articles remained for evaluation. After applying a second filter, i.e., papers published in Portuguese, English or Spanish in the last five years and conducted with adults and older people, 119 articles remained eligible for inclusion in the review. After applying the third filter, i.e., the exclusion of duplicate papers and papers published in more than one database, 78 articles remained for abstract review. Finally, after applying the fourth filter, i.e., evidence of an educational/pedagogical proposal, eight articles remained for analysis (as shown in Figure 1). These papers were read in full, using qualitative and contentbased comparative criteria, focusing on the educational/pedagogical approaches developed and a minimum level of quality, and using the STROBE scale Strengthening the Reporting of Observational studies in Epidemiology adapted by Berra et al., as shown in Table 1 (25 - 27).

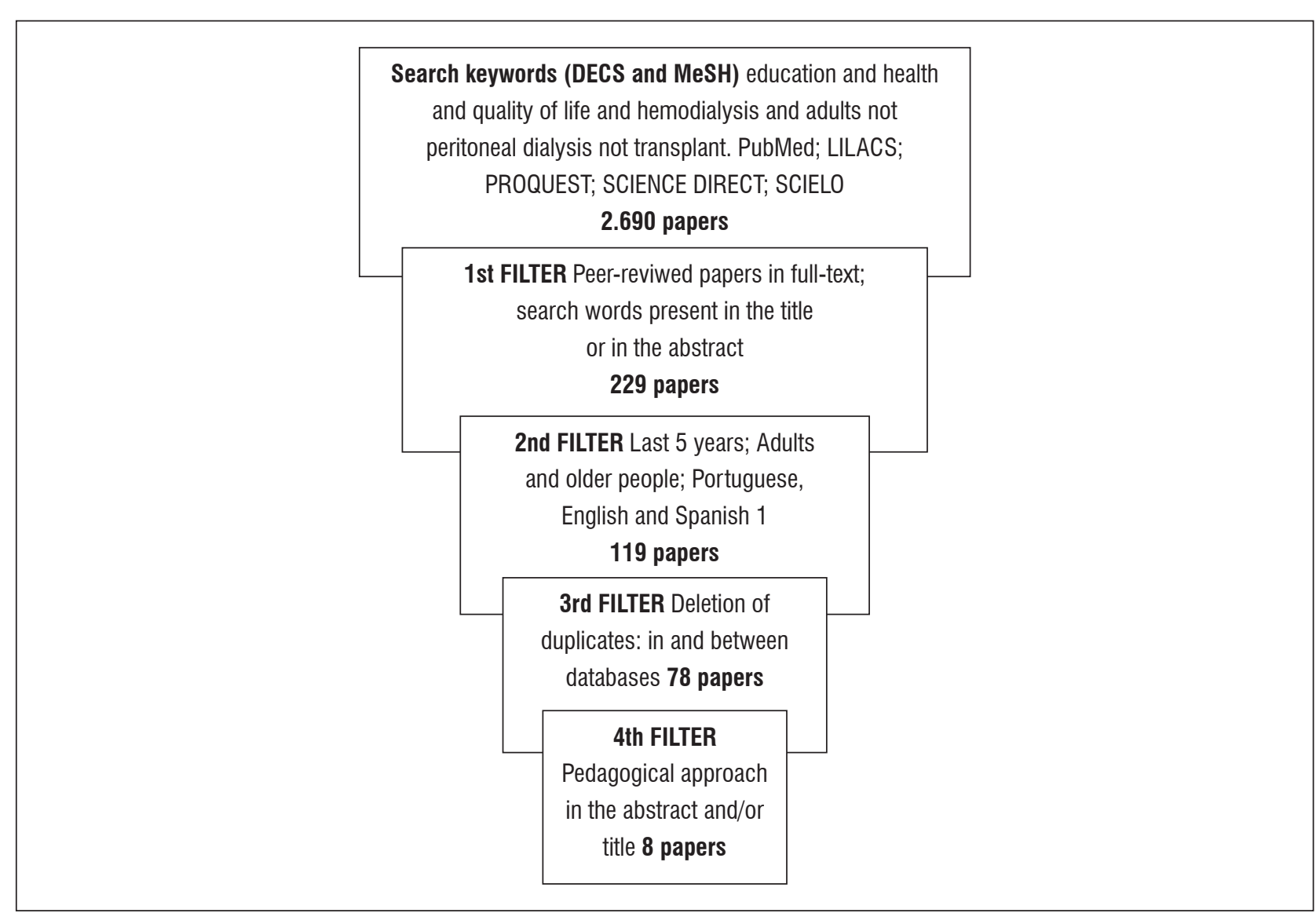

Figure 1 - Flow diagram of the steps followed and criteria used in selecting the papers that composed the sample; Curitiba, Brazil, 2015. 
Table 1 - Exhibit of the methodological quality of the papers in the sample, Curitiba, Brazil, 2015

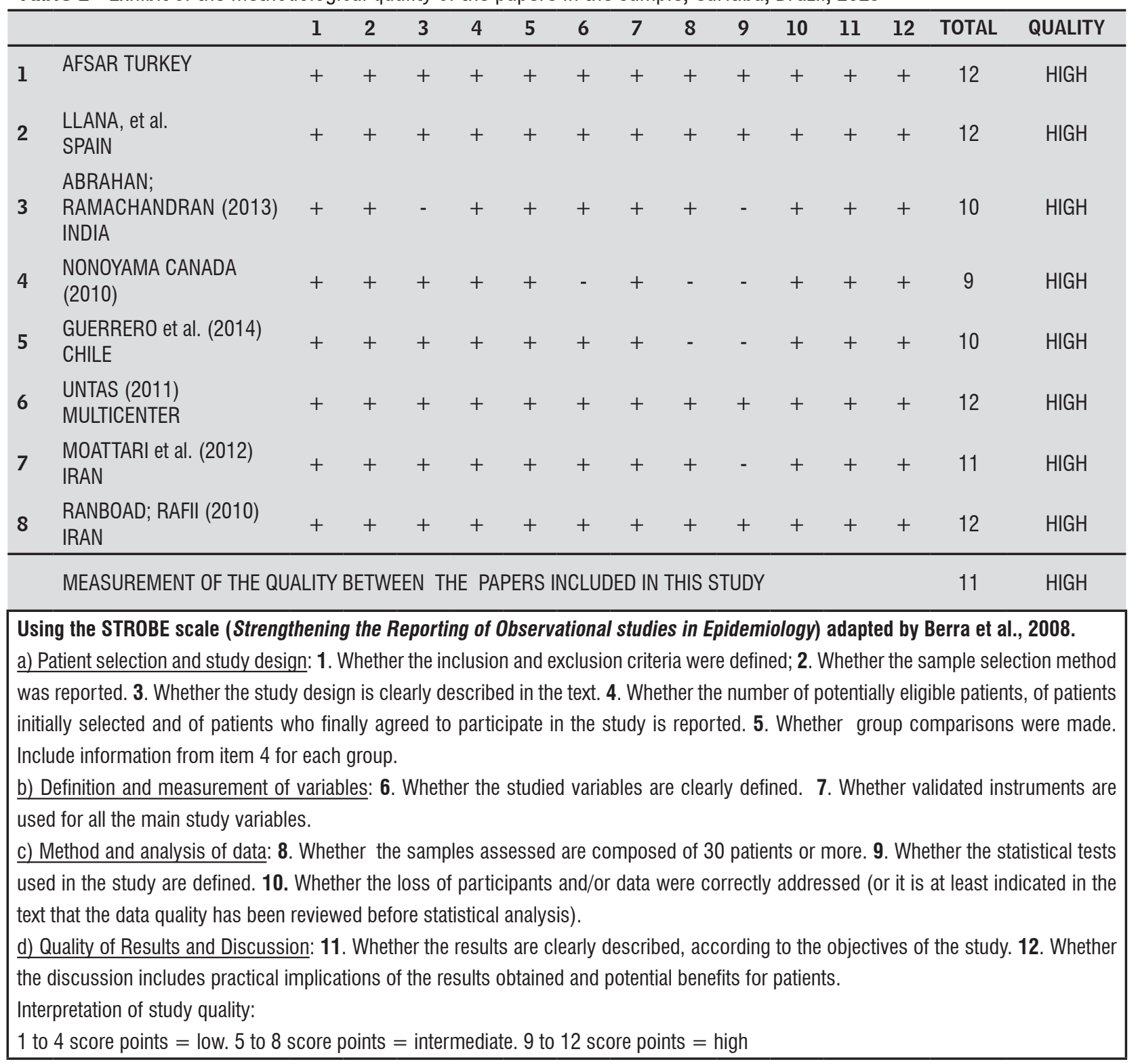

\section{Results}

From the articles included in this review, only one used qualitative analysis with phenomenological hermeneutics, all the other studies used quantitative approaches. With regard to the design of the studies, six studies performed cross-sectional analysis of the data, while two studies used longitudinal analysis. Regarding their collaborative scope, only one study was a multicenter study.

Most of the studies (4) were conducted in Asia, followed by Europe, South America and North America, with one study each. There was one multicenter study involving 12 countries: eight in Europe, two in America, one in Asia and one in Oceania. All studies reported receiving approval from a Research Ethics Committee and that participants signed an informed consent before beginning the study.

Only two studies had so-called "small samples", with less than 30 patients. The total number of patients included in seven studies (including the two studies with the so-called "small samples") was 519 (mean of 74.1 participants per study). The multicenter study involved 32,332 participants (from 12 countries and 4 continents) identified from a database of specialized service users. All studies included participants of age $\geq 18$ years and excluded participants with psycho-emotional disorders that could 
impair participation in the study (due to understanding or communication deficits).

In order to establish possible quality of life correlations in an educational/pedagogical manner, the studies addressed variables that included indicators of biological condition, adherence to treatment, psychosocial conditions and even spiritual influence. Regardless of the purpose and form of approach, all the studies were unanimous in recognizing the validity of educational processes for patients with chronic kidney disease receiving hemodialysis, whether focusing on treatment adherence, empowerment of actors, the importance of self-knowledge, the need to take a broad view of the patient, the importance of planning in the therapeutic approach and reflecting on the relationship between the disease and the health condition of the whole body.

\section{Discussion}

In this review, only 8 articles out of more than 2,600 initially identified dealt explicitly with the topic and had the educational proposal in their title or abstract, i.e., focused on the QoL of people with CKD using different educational proposals related to training, empowerment, adherence, advice, guidance, assessment of interrelations, perceptive description, or assessment of the impact of an educational program. The low number of studies retrieved evidences the gap in the current literature and reveals the incipient exploration of educational approaches focusing on patients, families and even health professionals working in specialized services.

Another important factor found in this review of the literature is that the issue of QoL has been almost exclusively dealt with in relation to patients' self-perception measures, through questionnaires and interviews, with few proposals of interventions targeting the improvement of QoL. These results raise the question of to what extent do professionals who treat people with CKD are also practicing/applying behaviors that promote QoL. A plausible hypothesis is that, despite the rhetorical importance usually given to the issue, the approaches used are limited to patients' self-perception measurements, which, without due intervention (professional care practices), become meaningless. Of note, of the studies reviewed, only one discussed the involvement of technical staff, whereas another one investigated the role played by the family in QoL.
Given the worldwide growing number of people with CKD, technical teams who treat such patients are expected to devote part of their efforts to implementing educational activities, in order to make patients understand and cooperate with their treatment and be prepared to cope with the resulting comorbidities. In this sense, many health professionals and researchers are increasingly concerned about the issues of quality of life and adherence to treatment in CKD patients $(28,29,30)$.

The educational approaches in health care practice are distinct and diverse, both in form and in scope. In a cross-sectional study conducted in Turkey with 134 patients, Afsar investigates the advantages and possible contributions of the use of the Internet (email, Facebook, Twitter) to instruct patients receiving hemodialysis. He points out that social media are useful information sources that show advantages over conventional sources such as books or newspapers, because they provide privacy in matters that may be embarrassing to patients, and can become a valuable ally to the health care team. People with higher educational levels have greater familiarity with the use of social media and show greater adherence to treatment in general. Another advantage of this educational format is the formation of groups of people with similar pathologies, who can learn and share experiences and knowledge. However, these findings about the use of social media in health care should not be considered conclusive and indicate the need for attention to the way in which they are used. It is necessary to question the quality of the sites visited for research purposes and whether supervision and guidance by specialized technical staff would not ensure better results. An informed and committed team can be decisive in guiding the educational process, helping in the selection of good evidence-based sources of information and advice $(31,32)$.

There are different tools to assess several QoL dimensions. These tools can be generic or specific, and comprise physical and biological indicators, indicators of social support, behavioral attitudes and even spiritual health. Counseling, as a way of educating for health, has been an important ally in the therapeutic intervention strategy for patients with CKD. However, despite its obvious efficiency and apparent simplicity, information-giving has not been a common practice in developing countries. On the other hand, in developed countries, information-giving has been a mandatory practice in the treatment of CKD patients 
receiving hemodialysis, and has been seen as a favorable factor for adherence and reduced morbidity and mortality in this population.

Llana's comparative study of hemodialysis versus peritoneal dialysis provides important information, showing that patients on peritoneal dialysis had better health-related quality of life (HRQoL) in the domains of physical functioning and bodily pain. Peritoneal dialysis patients had higher educational levels sought more information about the treatment, formed tighter bonds with health care staff, and were younger than their counterparts. This suggests that the nature of the intervention in peritoneal dialysis requires closer staff contact at a certain stage of treatment, as well as greater patient empowerment, since the latter will be responsible for much of the filtration intervention, which occurs outside the clinic environment and the direct control of professionals.

The type of dialysis used showed not to differentially affect patients' emotional state or adherence to drugs; however, patients receiving hemodialysis had greater control and knowledge of their food and water diets, which could be possibly due to the higher risk presented by hemodialysis (conduct of episodic nature) when compared to peritoneal dialysis (conduct of continuous nature). The findings of this study suggest that an important factor to be considered may be the passive and resigned nature of hemodialysis patients, which negatively affects treatment progress with respect to variables related to independence and autonomy. The results found point to the difficulties experienced by patients in adhering to oral medication in both types of dialysis, and the role that negative emotional state can play in the quality of life of these patients (4).

The study conducted by Abraham et al. (3) with a group of 50 patients (with control group) showed that the overall QoL of patients receiving hemodialysis was significantly impaired. The purpose of the aforementioned study was to test the influence of information-giving through oral and written guidance, materials on diet, exercise, lifestyle modification, importance of regular dialysis and six-month follow-ups on the QoL of hemodialysis patients, considering physical, psychological, environmental and social domains. It was found that the test group had better results in all the domains assessed, with the best results in the psychological domain, followed by the physical, then the social and finally the environmental domain. They also showed improved levels of concentration, thinking and learning. The authors concluded that the best performance in the psychological domain was associated with its closeness to spirituality, and that removing misconceptions about the disease increased positive feelings in patients (3).

Educational programs should have a comprehensive planning range both inside and outside treatment environments and in different areas related to health, so that relevant changes can be more lasting and contribute to the effective incorporation of concepts and values (33).

Nonoyama (34) proposed the implementation of an exercise program to be followed during hospital and home hemodialysis. The author found that adherence was higher during hospital sessions - under direct supervision and using appropriate equipment when compared to the same program developed at the patients' home. In addition to direct professional supervision and higher levels of individual attention, other positive factors to be considered when analyzing patients' high adherence to the program developed at hospital may be the fact that patients were actively involved in selecting the best exercise modality and the types of exercises to be performed during hemodialysis, which did not require any additional time beyond that already needed for hemodialysis. Reasons identified for low adherence to home exercise were lack of motivation and lack of time (34).

An integral part of the complex web of human relationships, people being treated for chronic diseases for various reasons end up moving away from their (different) social groups (family, friends, work). The losses resulting from this isolation cannot always be calculated, but are, however, worthy of attention, research and intervention.

The study by Untas (35) highlighted the importance of social support, correlating it with a person's perception of being part of a complex network of relationships that provides her/him with affection and assistance, but also gives her/him responsibilities. Such network may be composed of different actors, such as the family, friends, the community, and even members of the multidisciplinary team. However, Untas notes with surprise that, in his study, the encouragement and support received from the staff were not associated with patient adherence to treatment, while other social factors, such as family support, were. This observation is relevant since it raises questions about the fact that even though hemodialysis patients are linked to a treatment plan that gives them obligations 
regarding timeliness and frequency, and makes them depend on a multidisciplinary team, the relationship with the team may be restricted to a purely physical and technical closeness. Other studies have claimed that patients should be seen and treated in a more individualized fashion to best address their needs and expectations, that making patients feel safe and welcomed by the staff is of fundamental importance, and that patient embracement includes truly listening to each patient (35) .

Patients with so-called chronic diseases adopt different ways of coping with changes in their health condition. They often have difficulties accepting the disease and its consequences. 'Fighting' against the disease could be seen as correct, because not accepting the degrading conditions it can produce would mean contributing to treatment. However, patients sometimes unconsciously fight and avoid everything that may be related to their new health condition, rejecting not only the people but also treatment itself and everything that may be associated with it, such as guidance, advice, restrictions and responsibilities (36).

Guerrero (7), points to the importance of "embracing" the changes brought about by the disease. Embracing here does not mean accepting them passively, but taking control over its management, including its course, restrictions and implications, and adhering to, collaborating with and actively participating in treatment. Diseased patients usually have their bodies invaded, which changes their communication and connection with the world, in this natural form of dialogue. Other transformation factors are identified as relevant: treatment duration is pointed out as too long and considered to represent important losses in life; adherence to drugs is reported as being a complex problem due to their amount, diversity and time schedule; diet restrictions is the biggest complaint patients have - not the quality, but rather the quantity of what can be eaten. In this context, people with CKD describe their relationship with the disease by differentiating between two moments: before and after the disease. Before the diagnosis, they lived a healthy life, without complications and treatments. After the diagnosis, they go through important changes in their ways of existing in the world. These changes are described as being no longer in control of daily life activities, experiencing losses in relationships with friends and family members, losing their "healthy person identity", experiencing losses in physical condition and social motivation, and being no longer in control of their body's vital functions. The need to be connected to a machine leads to a strange and disturbed relationship of love and hate, of not wanting to be part of it and being aware that you need it to survive. The authors highlight that, in order to achieve better results in the relationship between staff and patients, individual aspects of their life experience should be taken into consideration, such as cognitive skills, social difficulties, preferences, priorities, social habits, family networks, the different roles played by patients, the channels of communication, trust, empathy, understanding and receptivity (7).

The findings by Untas and Guerrero reinforce the understanding that patients' "being" and "existing" in the world are drastically modified by chronic kidney disease. We should, therefore, ask ourselves to what extent health care teams and the health system are prepared to treat chronic patients in a strategic and comprehensive manner, knowing that it is necessary to allocate enough time in the approaches to plan, direct and customise education actions and the empowerment of patients, families and society itself, contributing to the construction of a greater sense of security and adherence to treatment (35).

Empowerment is one of the educational strategies available. It has no specific meaning and derives from power. The word power is used in many contexts and has several different meanings that are adapted according to different needs and understandings. In the field of health, empowerment is a term that is being increasingly used to describe patients' ability to self-manage their care. To empower is not an easy task! On the contrary, it is a condition that should promote a negotiation process and take into account patients' needs with regard to their personal, social and cultural particularities. Empowerment, as cited in the Ottawa Charter from the Pan American Health Organization, can be understood as the educational process that aims to develop self-knowledge skills and attitudes, so that patients take responsibly for decisions and choices made about their health $(33,36)$.

In an experimental study, Moattari (37) carried out a behavior change program based on patients' priorities; sessions focused on stress management, concentrating on the problem and on coping strategies, social support and motivation, and emotion. Significant improvements were found in two selfefficacy components (decision-making and stress reduction), whereas no improvement was observed 
in positive attitudes. The authors attributed the improvements in decision-making and stress to the nature of the proposal (based on individual and family support for problem solving) and to the individual sessions of relaxation training. The lack of success found in "positive attitudes" was attributed to very short follow-up time for conditions judged as very complex by patients. They conclude that training/ empowerment programs have a direct impact on decision making, stress reduction and quality of life, and can facilitate adherence to self-care, including with regard to clinical variables (37).

Rambod et al. (38) conducted a cross-sectional study with 202 Iranian patients receiving hemodialysis. The purpose of the study was to investigate the relationship between perceived social support and QoL in patients, by analyzing the following variables: perceived social support, functional health, socioeconomic, psychological and spiritual conditions and quality of life. The authors used instruments to assess quality of life, mental conditions, social and environmental data, among others. The authors highlight important aspects to be considered in studies with Muslim populations: the belief that health is a gift from Allah (God) and that the disease is a test that has to be passed; although what happens to them is God's will, they should not stand idle when crisis occurs; that adherence to spiritual practices is strongly recommended, in order to improve the ability to deal with crises, as well as the recitation of the Qur'an, which offers positive values to help them face these kind of situations (recommending emotional support, kindness, love, kindness to parents, relatives, friends, neighbors, orphans and poor people); and that families are considered the support haven in times of crisis. The final results showed a statistically significant relationship between the perception of social support and health functioning, social, economic, psychological and spiritual factors and theQoL subscales. The results also suggest that efforts should be directed at improving family-related social support among dissatisfied chronic patients, as better QoL results were found among married patients (38).

\section{Conclusion}

We conclude that the educational approaches related to the quality of life of people with CKD receiving hemodialysis are many and varied, be it with regard to their design, instruments or way of conduction. Our reveal of the literature reveals, however, that the number of educational approaches focusing on this group of patients, their families and the technical staff is still modest and little representative. Nevertheless, the few studies that address the topic from an educational viewpoint are unanimous in recognizing that the approach to CKD patients receiving hemodialysis should not be limited to renal replacement therapy. It is crucial to consider, among other things, the patient's culture, customs, personal individualities and sociodemographic conditions. In the educational process, patient empowerment, adherence and participation, as well as the participation of family members, the technical team and the community should be considered when approaching people with CKD receiving hemodialysis.

\section{References}

1. Kojima M. Epidemiologic studies of psychosocial factors associated with quality of life among patients with chronic diseases in Japan. J Epidemiol. 2012;22(1):7-11.

2. Yusop NBM, Mun CY, Shariff ZM, Huat CB. Factors associated with quality of life among hemodialysis patients in Malaysia. PLoS One. 2013;8(12):e84152.

3. Abraham S, Venu A, Ramachandran A, Chandran PM, Abraham S. Assessment of Quality of Life in Patients on Hemodialysis and the Impact of Counseling. Saudi J Kidney Dis Transpl. 2012;23(5):953-7.

4. Llana HG, Remor E, Selgas R. Adherence to treatment, emotional state and quality of life in patients with end-stage renal disease undergoing dialysis. Psicothema. 2013;25(1):79-86.

5. Rodrigues DF, Schwartz E, Santana MG, Zillmer JGV, Viegas AC, Santos BP, et al. Vivências dos homens submetidos à hemodiálise acerca de sua sexualidade. Av Enferm. 2011;29(2):255-62.

6. Magnard J, Deschamps T, Cornu C, Paris A, Hristea D. Effects of a six-month intradialytic physical ACTIvity program and adequate NUTritional support on protein-energy wasting, physical functioning and quality of life in chronic hemodialysis patients: ACTINUT study protocol for a randomised controlled trial. BMC Nephrology. 2013;14:259. 
7. Guerra-Guerrerro V, Plazas Mdel P, Cameron BL, Salas AV, González CG. Understanding the life experience of people on hemodialysis: adherence to treatment and quality of life. Nephrol Nurs J. 2014;41(3):289-97, 316; quiz 298.

8. Maldaner CR, Brondani CM, Budó MDLD, Pauletto MR. Fatores que influenciam a adesão ao tratamento na doença crônica. Rev Gaucha Enferm. 2008;29(4):647-53.

9. Mandoorah QM, Shaheen FA, Mandoorah SM. Impact of kidney diseases and transplantation renal data from the arab world impact of demographic and comorbid conditions on quality of life of hemodialysis patients : a cross-sectional study. Saudi J Kidney Dis Transpl. 2014;25(2):432-7.

10. Rayner HC, Zepel L, Fuller DS, Morgenstern H, Karaboyas A, Culleton BF, et al. Recovery time, quality of life, and mortality in hemodialysis patients: the Dialysis Outcomes and Practice Patterns Study (DOPPS). Am J Kidney Dis. 2014;64(1):86-94.

11. Rostami Z, Lessan Pezeshki M, Soleimani Najaf Abadi A, Einollahi B. Health related quality of life in Iranian hemodialysis patients with viral hepatitis: changing epidemiology. Hepat Mon. 2013;13(6):e9611.

12. Mendes EV. As redes de atenção à saúde. Brasília: Organização Pan-Americana da Saúde; 2011. 554 p. Portuguese.

13. Figueiredo MFS, Rodrigues-Neto JF, Leite MTS. Modelos aplicados às atividades de educação em saúde. Rev Bras Enferm. 2010;63(1):117-21.

14. Pagliosa FL, Da Ros MA. O relatório Flexner: para o bem e para o mal. Rev Bras Educ Med. 2008;32(4):492-9.

15. Silva G, Nóbrega JYDL, Nóbrega AL, Araújo RLD, Silva NQ Nóbrega MF, et al. Percepção de portadores de doença renal crônica com relação ao tratamento hemodialítico. INTESA. 2015;9(1):23-30.

16. Aguiar RAT. A construção internacional do conceito de atenção primária à saúde (aps) e sua influência na emergência e consolidação do sistema único de saúde no Brasil [master's thesis]. Belo Horizonte (Brazil): Universidade Federal de Minas; 2003. Portuguese.

17. Queiroz MVO, Dantas MCQ, Ramos IC, Jorge MSB. Tecnologia do cuidado ao paciente renal crônico: enfoque educativo-terapêutico a partir das necessidades dos sujeitos. Texto Contexto - Enferm. 2008;17(1):55-63.
18. Portal Brasil. Doença renal crônica atinge $10 \%$ da população mundial. 2015 [cited 2016 Jun 24]. Available from: <http://tinyurl.com/jax3wlu>.

19. Bastos RMR, Bastos MG, Teixeira MTB. A doença renal crônica e os desafios da atenção primária à saúde na sua detecção precoce. Revista APS. 2007;10(1):46-55.

20. Cavalcante MC, Lamy ZC, Lamy Filho F, França AK, Santos AM, Thomaz EB, et al. Factors associated with the quality of life of adults subjected to hemodialysis in a city in northeast Brazil. J Bras Nefrol. 2013;35(2):79-86.

21. Ferreira RC, Silva Filho CR. Quality of life of chronic renal patients on hemodyalisis in Marilia, SP, Brazil. J Bras Nefrol. 2011;33(2):129-35.

22. Md Yusop NB, Yoke Mun C, Shariff ZM, Beng Huat C. Factors associated with quality of life among hemodialysis patients in Malaysia. PLoS One. 2013;8(12):e84152.

23. Bilgic A, Akgul A, Sezer S, Arat Z, Ozdemir FN, Haberal M. Nutritional status and depression, sleep disorder, and quality of life in hemodialysis patients. J Ren Nutr. 2007;17(6):381-8.

24. Santos ACB, Machado MDC, Pereira LR, Abreu JLP, Lyra MB. Association between the level of quality of life and nutritional status in patients undergoing chronic renal hemodialysis. J Bras Nefrol. 2013;35(4):279-88.

25. Guerrero VG, Alvarado OS, Espina MC. Qualidade de vida de pessoas em hemodiálise crônica: relação com variáveis sociodemográficas, médico-clínicas e de laboratório. Rev Latino-Am Enferm. 2012;20(5):838-46.

26. Victoria F, Danquah N, Bergstrom N. Quality of Life Measures for Patients On Hemodialysis: A Review of Psychometric Properties. Nephrol Nurs J. 2010;37(3):255-69.

27. Vero LM, Byham-Gray L, Parrott JS, Steiber AL. Use of the subjective global assessment to predict health-related quality of life in chronic kidney disease stage 5 patients on maintenance hemodialysis. J Ren Nutr. 2013;23(2):141-7.

28. García-Llana H, Remor E, Del Peso G, Selgas R. E El papel de la depresión, la ansiedad, el estrés y la adhesión al tratamiento en la calidad de vida relacionada con la salud en pacientes en diálisis: revisión sistemática de la literatura. Nefrologia. 2014;34(5):637-57. Spanish.

29. Ciapponi A. Artículo Especial : Guía de lectura crítica de estudios observacionales en epidemiología (primera parte). Evidencia. 2010;13(4):135-40. Spanish. 
30. Malta M, Cardoso LO, Bastos FI, Magnanini MMF, Silva CMFP. Iniciativa STROBE : subsídios para a comunicação de estudos observacionais. Rev Saude Publica. 2010;44(3):559-65.

31. Nissenson AR. Improving outcomes for ESRD patients: Shifting the quality paradigm. Clin J Am Soc Nephrol. 2014;9(2):430-4.

32. Afsar B. The relation between Internet and social media use and the demographic and clinical parameters, quality of life, depression, cognitive function and sleep quality in hemodialysis patients: Social media and hemodialysis. Gen Hosp Psychiatry. 2013;35(6):625-30.

33. Taddeo PS, Gomes KVL, Caprara A, Gomes AMA, Oliveira GC, Moreira TMM. Acesso, prática educativa e empoderamento de pacientes com doenças crônicas. Cienc Saude Coletiva. 2012;17(11)2923-30.

34. Nonoyama ML, Brooks D, Ponikvar A, Jassal SV, Kontos P, Devins GM, et al. Exercise program to enhance physical performance and quality of life of older hemodialysis patients: a feasibility study. Int Urol Nephrol. 2010;42(4):1125-30.
35. Untas A, Thumma J, Rascle N, Rayner H, Mapes D, Lopes AA, et al. The associations of social support and other psychosocial factors with mortality and quality of life in the dialysis outcomes and practice patterns study. Clin J Am Soc Nephrol. 2011;6(1):142-52.

36. Wendhausen ALP, Barbosa TM, Borba MC. Empoderamento e recursos para a participação em conselhos gestores. Saude Soc. 2006;15(3):131-44.

37. Moattari M, Ebrahimi M, Sharifi N, Rouzbeh J. The effect of empowerment on the self-efficacy, quality of life and clinical and laboratory indicators of patients treated with hemodialysis: a randomized controlled trial. Health Qual Life Outcomes. 2012;10:115.

38. Rambod M, Rafii F. Perceived social support and quality of life in Iranian hemodialysis patients. J Nurs Scholarsh. 2010;42(3):242-9.

Received in 05/19/2016

Recebido em 19/05/2016

Approved in 07/21/2016

Aprovado em 21/07/2016 